\title{
Feminine Features as Political Tools: The Cases of Femen and Women of Liberia ${ }^{1}$
}

\section{Rasgos femeninos como herramientas políticas: los casos de Femen y Mujeres de Liberia}

\author{
Gabriela Caviedes ${ }^{2}$ \\ Universidad de los Andes (Chile)
}

Recibido: 30-11-16

Aprobado: 07-01-17

\begin{abstract}
This paper is an analysis of the different ways in which feminism can be understood, using as examples the cases of the feminist movements Femen and Women of Liberia. Both are distinguished by using feminine features as political tools, and both have been an issue of interest for audiovisual productions. Each one is the main subject of two documentaries: Ukraine is not a Brothel, that concerns Femen movement; and Pray the Devil Back to Hell, that concerns Women of Liberia movement. I shall use this material in order to present each. After presenting them I will analyze them in light of the definition and division of feminism that Karen Offen, scholar of the University of California, does. I will then conclude that Femen is an example of what she calls 'individualistic feminism', and Women of Liberia an example of what she named 'relational feminism'. I will also conclude that the political position they achieve is also due to the branch of feminism they represent.
\end{abstract}

Key-words: Feminism, Femen, Ukraine Is Not a Brothel, Woman of Liberia, Pray the Devil Back to Hell.

\footnotetext{
${ }^{1}$ La elaboración de este trabajo ha contado con el financiamiento de la Comisión Nacional de Ciencia y Tecnología de Chile, CONICYT-PFCHA/Doctorado Nacional/2016-21160065.

2 (gscaviedes@miuandes.cl). Gabriela Caviedes es doctoranda en Filosofía en la Universidad de los Andes, Chile. Es profesora de Antropología y Ética, y miembro del Grupo de Investigación en Filosofía Práctica en la misma universidad. Sus líneas de investigación son filosofía contemporánea y ética de la ley natural. Sus últimas publicaciones son: "Absolutos morales en la Teoría Neoclásica de la ley natural". (Aceptada en revista Pensamiento) y García-Huidobro, J. y Caviedes, G.: "Pain and Beauty as the Guarantee of Truth" (Aceptada en The Chesterton Review).
} 


\section{Resumen}

Este trabajo es un análisis de los distintos modos en que puede entenderse el feminismo, usando como ejemplos los casos de los movimientos feministas Femen y Mujeres de Liberia. Ambos se distinguen por usar características femeninas como herramientas políticas, y ambos han sido objeto de interés para producciones audiovisuales. En efecto, cada uno constituye la temática central de dos documentales: Ukraine is Not a Brothel ("Ucrania no es un burdel"), que trata del movimiento Femen; y Pray the Devil Back to Hell ("Reza para que el diablo regrese al infierno"), que trata del movimiento Mujeres de Liberia. Usaré este material para presentar cada uno. Luego los analizaré a la luz de la definición y división del feminismo que realiza Karen Offen, académica de la Universidad de California. Concluiré luego que Femen es un ejemplo de lo que ella llama "feminismo individualista", y Mujeres de Liberia, de lo que llama "feminismo relacional". También concluiré que la posición política que alcanzan se debe también a la rama de feminismo que representan.

Palabras-clave: Feminismo, Femen, Ukraine Is Not a Brothel, Mujeres de Liberia, Pray the Devil Back to Hell.

A few months ago, I was attending a seminary of a renowned English feminist. At a certain point, a girl in the public rose her hand and asked the following question: "I can't understand why some women do not recognize themselves as feminists. How can anyone be a woman and not want to defend woman's rights?". Her question was completely appropriate. In fact, we could say, that question touches one of the problems that lies in the heart of feminism: that there is a general confusion about what it is exactly, what does it want, and how does it want to achieve what it wants.

There are few concepts so used but also so misunderstood as feminism. Indeed, it seems that the very word, though transversely used in political and public speeches, rises up fervent supporters, but at the same time fears and rejections. There are strong and serious struggles even among the most enthusiastic feminist activists and thinkers, and, as the previously named girl in the audience said, many women would not recognize themselves as part of the movement, even when, knowing it or not, they would tend to support at least some of the goals it intends. Partly, the reason is that under the flag of feminism, women (and many men as well) defend many different aims, using a multiplicity of methods, and assuming diverse and in some cases contradictory principles.

Nobody doubts, nevertheless, that feminism is a political movement: it tries to achieve, through a particular public method, changes in society 
concerning women's unjust situation in the world, or in a certain country or culture. Political was the suffragist movement of the $19^{\text {th }}$ century in Europe and America, that through massive protests claimed for the women's right to vote. Political was as well the Argentinian feminist movement of that same century, that through the dissemination of the first anarcha-feminist newspaper La Voz de la Mujer (The Voice of the Woman) demanded the end of the women's sexual and work harassment. Pan y Rosas (Bread and Roses) is a current Latin American anarcha-feminist movement that demand sexual and reproductive rights for woman through massive protests.

There have been some feminist movements that have used the very feminine features as a political tool. I shall present here two of the most revolutionary ones in this century: Femen, Ukrainian movement for the woman's liberation; and Women of Liberia, movement that claimed for the ending of the civil war in their country, and the stopping of the Blood Diamonds disaster in Sierra Leone. The analysis will be based on two documentary films: Ukraine is Not a Brothel (2013) and Pray the Devil Back to Hell (2008). These are not historical documentaries. They are political. Their intention is not simply to inform, but to create an opinion about Femen and Women of Liberia. The first documentary is highly critical, though it was produced and filmed by one of the militants of Femen. The second one is laudatory, and tries to move to true admiration by the Liberian feminists.

After presenting the stories, I will analyze them in light of the definition and division of feminism that Karen Offen, a historian from the Institute for Gender Research at Stanford University, offers ${ }^{3}$. Her view and proposal is interesting for three reasons: first, because she recognizes the lack of a proper definition of feminism and the confusion that problem brings, so she attempts to give an accurate definition from an ideologically neutral field. Second, because, as a historian, she includes relevant historical data that allows to identify current feminism essentially as the same movement than the one emerging in the mid$19^{\text {th }}$ century. And third, because her definition and division of feminism helps understanding what feminism is, what all feminist have in common and how do they diverge, in a way that it is possible to catalogue different feminist movements in the two branches she identifies.

\section{Ukraine Is Not a Brothel: The Cry of Ukrainian Prostitutes}

Ukraine's territory had been historically invaded by different European people. In the late $18^{\text {th }}$ century, it was progressively divided between Russia

3 Offen, K. (1988). Defining Feminism: A Comparative Historical Approach. Signs 14 (1), 119157. Though the paper is almost twenty years old, her insights are completely current. 
and Austria ${ }^{4}$. Before the outbreak of the First World War, Ukraine was totally dominated by both countries (which meant half of the Ukrainian soldiers had to fight for the Allies, and the other half for the Central Powers). After the First War, both Russia and Austria collapsed, so Ukraine took advantage of the situation and started a national movement for the independence. It created the Ukrainian Soviet Socialist Republic, or Soviet Ukraine (Kubicek: 2008). But a civil war quickly weakened Ukraine's strength, brought hunger, and once again Ukraine was attached to the Russian Union of Soviet Socialists Republics in 1922, under the leadership of Joseph Stalin.

As almost every country in Europe, the USSR was highly damaged by the Second World War. Economically, the countries that conformed the Union were devastated, and the decades that followed the end of the Great War produced an important economic decrease in the Soviet Union. This situation got even worse after the breaking up of the USRR. Ukraine was, economically speaking, thought to be the best positioned amongst the ex-USSR countries but it was actually the opposite. Between 1991 and 1999, Ukraine went through a deep crisis. It suffered serious hyperinflation, and by 1999 its GDP had fallen to less than 50\% the 1991 level (Magocsi 2010). Most of Ukrainian people sank in extreme poverty, and tried to survive by working in more than one place at a time, growing their own food, or bartering. Many women fell into prostitution, and many others, who tried to leave the country looking for job opportunities, also ended up prostituting themselves, but abroad (Kubicek 2008).

Ukraine's economy stabled a bit by the 2000's (though not completely, and suffering some other economic depressions), and Ukrainian men were able to find new jobs. But women didn't. Many still find prostitution as their only way of living. Not only Ukrainian men sees them as prostitutes, but also the whole world. Some tourists visit Ukraine searching their women, who are in many cases willing to meet a foreign man by Internet to marry him as a way to leave her country for a better life ${ }^{5}$. Is in this context that Femen emerges, and is the sad background that Ukraine Is Not a Brothel shows by the beginning of the documentary.

Ukraine Is Not a Brothel was released on September 2013, and it concerns the Femen movement. The director is Kitty Green, who formed part of the movement for over a year, and so knows it from the inside, as well as all activists. The documentary shows, in a revealingly disorganized way, how the main characters of the movement see Femen, and how they feel about it.

${ }^{4}$ For Ukrainian history, cf. Magocsi, P.R. (2010). A History of Ukraine: The Land and Its People ( $2^{\text {nd }}$ ed.), Toronto: University of Toronto Press; Subtelny, O. (2009). Ukraine: A History. Toronto: University of Toronto Press; Kubicek, P. (2008). The History of Ukraine. Westport: Greenwood; Plokhy, S. (2015). The Gates of Europe: A History of Ukraine. New York: Basic Books.

5 There are, in fact, many web sites offering young ukrainian (and, in general, Slavic) women for marriage. Pages such as www.russian-ukrainian-women.com, www.ukrainewoman.net or www.cityof-brides.net are worldwide known. 
Green dedicates enough time for each of the girls to feel free to speak. She interviews Inna Shevchenko, Sasha (Alexandra) Shevchenko, Anna Hutsol, Oksana Shacko, and finally Victor Svyatski, whose role in Femen will come to light by the end of the film.

First thing Kitty Green wants to make clear is the undeniably pitiful situation of the Ukrainian women. She starts by filming Sasha, who explains how Ukraine's economic collapse led women to prostitution, and how Femen emerges as a desperate resource to cry for freedom. They don't want to be sexual objects anymore. They don't want to be abused anymore. They want men to stop seeing them as exploitable Ukrainian products, and start considering them as equal.

What's remarkable, and what led Femen to international fame, is the way they decided to reach their objective. Green shows, in a minute of rapid flash images, a summary of what Femen is, what it does, and how it does it. Among the many pictures that collect past protests, swiftly passing through the spectator's eyes, it is possible to recognize Femen's motto: "Our God is a Woman! Our Mission is Protest! Our Weapon are bare breasts!", as well as the phrase, painted in black: "Political Porn". Femen movement is worldwide known for being a radical feminist movement whose activist are always gorgeous naked women that write, painting their bare breasts, what they are protesting about. Why that method? Inna Shevchenko explains it: "it's true that nobody in this country wants to listen to women. Nobody takes a woman seriously, but everyone wants to look at women. Everyone wants to see beautiful, sexy woman, naked woman". Sasha Shevchenko complements Inna: "we need to do everything we can so that the world sees Ukraine as a country where naked girls protest, not sell their bodies".

Femen's protests are peaceful, in the sense that they don't mean to hurt or kill anybody, and they don't carry weapons. But they are aggressive: they intend to make as much noise and scandal as they can in every protest. Green shows in the film how some of them take place. They gather at a public place, like a cathedral or a public square, they undress, showing their message painted in their bodies, and start screaming against the government and the $\mathrm{Church}^{6}$, or just making enough noise to make sure they catch everyone's attention.

It is to foresee that the authorities did not take the protests very well. First years, naked women protesting were arrested and kept in prison for a couple of days (days in which, as Oksana Shacko tells, policemen usually hit them, insulted them, and tried to touch or abuse them). But since Femen didn't mean to stop, the government enacted a law that penalized those protests as criminal acts, so activists started risking up to five years in prison, reason why Femen activists started to need protection from lawyers.

\footnotetext{
${ }^{6}$ Slavic countries are mainly orthodox christians.
} 
Green's film tries to be as loyal as it can to reality. Only part of her scenes are interviews. She uses her camera as any amateur with a mobile phone would, because she wants to show how Femen works from the inside. She catches the scheduling of the protest (sometimes covering her camera for her own security and her partners', in such a way that it is only possible to hear, but not see) and the Skype conversations activists maintain. The enacting of the law that criminalized protests happened just during the production of the documentary, so Green was able to capture the glances of doubt among the eyes of the activists, followed by inner determination. They are willing to accept prison as consequence, if they must. But Green wants to show something else based on that issue: the activists' parents grief.

Green films a Skype conversation between Sasha and her parents, taking good care not to be reached by the activist's laptop camera. Those parents are, as anyone could imagine, really concerned about their daughter: she might be imprisoned now, so they want to take her home once and for all. They want to stop her meeting with Inna, and Sasha's mother threatens to go to the medias and tell everyone about Victor. Sasha, visibly upset, hangs up. This is the first time the spectator hears about Victor. Green uses the opportunity to address the issue. She interviews Sasha's mother, and her statement is enlightening:

In my opinion, Femen is an invention of Victor's schizophrenia. He lives off the money that he makes from Femen. Where in his head did this come from? It started like a nice charitable organization [...]. But Femen now is entirely different. Victor just yells at them. I can't see how they are doing any good. All I see is the sick brain of Victor, because a normal man would never have thought up this method of protest. I know that he comes up with the ideas. I know for sure that he designs the protests, and the stupid thing is that they all listen to him and do what he says [...]. Cry? Yes, I cry every day.

Someone could think that this are the statements of a hurt, over-protective mother. But Kitty Green wants to clear every doubt. She now faces Victor and then the girls about this particular, delicate matter.

Victor shows up anonymously at first. Laughing nervously, covering his face with a rabbit mask. But as things get serious, he takes it off. For the first time, we hear Kitty's voice. She wants everyone to hear what she is asking, like if she was trying to get thousands of witnesses. She wants everybody to hear and see Victor say that girls are weak, that they don't have strength of character, that they are submissive, spineless and unpunctual, crucial political factors that he had to teach them. Green wants everybody to know that Victor recognize his participation in Femen is contradictory. That his patriarchal influence is the very same as the one they are protesting against, though, as he believes, his help is as paradoxical as undeniable, as Marx or Lenin, bourgeoisies, fought 
against bourgeoisie. And Green wants to emphasize particularly the following dialogue:

Green: You once said men did everything for sex. Did you start Femen to get girls?

Victor: Kitty...

Green: Did you or did you not? Is this your motivation? Partly at least?

Victor: Yes! Perhaps yes, somewhere in my deep subconscious. I would be an idiot, I would be really dishonest, if I said definitely not [...]. This patriarchal system... it takes everything away from women, every path, every perspective, and leaves woman placed in a sexual pedestal. Unfortunately, that's how it is.

Still, this could be manipulation ${ }^{7}$. Green is not satisfied yet. She secretly films scenes where Victor yells and insults the girls. She films their faces of fear as they hear Victor's outbursts. And finally, she pushes Inna, Sasha and Oksana to talk about the man that controls all of them. When she asks Sasha about who is the real leader of Femen, Sasha doubts, as she whispers "Kitty...!", begging her with her eyes. When Oksana is asked if Femen is a feminist movement, she moves nervously in her seat:

Well you... you can't really say that. In society there exist such a relationship: men lead women, and psychologically for women... they believe they need to be under a man's control. And when we were first getting started, the first phase... I don't think that Femen could have come about in any other way. We couldn't have come up with this ourselves. We wouldn't have done it. We needed that push: the help of a man. Because it's like... the law.

Especially meaningful is the laughter and resigned glance of the current leader of Femen, Inna Shevchenko. By the end of the film, she parodies, with her natural good humor: "'We are against patriarchy!' (she laughs. Then she rises her eyes, as in a plea). Are you a man? Please help us!”.

Obviously, this is not a situation a woman that tries to free from patriarchal control would want. Inna and Sasha delicately expressed their wish to free from Victor, though some of the girls seemed to doubt of Femen's success without him. They all understood, nevertheless, that they were being mistreated, and somehow they needed that to stop. As we well see later, after the releasing of the documentary, Victor's behavior was disclosed to the world, the girls managed to dismiss him from the movement, and kept along by themselves much more successfully.

\footnotetext{
${ }^{7}$ In fact, one could wonder why Victor agreed to expose himself in such a way. That is, to say the least, suspicious. But, as Green would tell later in an interview, neither the girls nor Victor really knew what Kitty was up to by filming them, so they let her do (within some limits she tried to overpass). When she told them she was going to release a documentary, Victor yelled and threatened her, and the girls treated her as a traitor (Retrieved August 9, 2016, from http://www.vice.com/read/we-spoke-tokitty-green-about-her-femen-documentary-ukraine-is-not-a-brothel).
} 


\section{Pray the Devil Back to Hell: A Group of Women Fighting for Peace}

Liberia, capital Monrovia, is an African country located in the northwest coast of the continent ${ }^{8}$. It borders Sierra Leone and Guinea on the north, and Ivory Coast on the east. Though originally it was simply vast territory occupied by different tribes (as most of African soil), in the $19^{\text {th }}$ century Liberia was founded as a country by the United States, in order to send the liberated African-American slaves. The colonization process started in 1820, and Liberia was proclaimed as an independent nation on 1847 .

Only 5\% of the Liberian population came from America. The vast majority were African natives. But the new immigrants brought American traditions and culture, so they subdue aborigines by using modern technology and American political institutions. They also had internalized the idea that paler skin and hair were superior, and since most of them were mixed-raced, they were actually paler than African inhabitants. So colonist established in their new country the racist system they had just escaped from, a system where they, AmericanLiberians, were socially in a higher range than the rest of the 'black' population (Harris 2012).

The new social hierarchy had political consequences. For more than a century, only the elite reached the presidency, until Samuel Doe, a young man from the ethnical group of the Krahn, organized a coup against the president William Tolbert and his government on 1980. Doe was the first native Liberian president. His government was, nevertheless, extremely cruel and repressive, which brought several rebellions and, eventually, the outbreak of the First Civil War on 1989. War faced Doe's Liberian army against the National Patriotic Front of Liberia (NPFL), leaded by Charles Taylor. By 1990, Doe was captured, tortured and killed; and Taylor became president in 1997 (Waugh: 2011). During his government, internal rebellions kept weakening Liberia, so he spent his whole time dealing with a Second Civil War, especially fighting against a group of extremely violent rebels called Liberians United by the Reconciliation and Democracy (LURD). Besides, he wanted to support rebels in neighbor countries: Taylor's government started selling military weapons to Sierra Leone in exchange for its diamonds (Waugh 2011).

War is always a lose-lose situation. Everybody loses something infinitely more valuable than what is eventually gained. Liberian women were wide aware of that reality. For them, war was always men's thing. And in the particular case of Liberia, a greedy selfish men's thing. Taylor was only thirsty of more power,

\footnotetext{
${ }^{8}$ For Liberian history, cf. Everill B. (2013). Abolition and Empire in Sierra Leone and Liberia. Hampshire: Palgrave Macmillan UK; Waugh, C. (2011). Charles Taylor and Liberia: Ambition and Atrocity in Liberia's Lone Star State. London: Zed Books; Harris, D.J. (2012). Civil War and Democracy in West Africa: conflict resolution, elections and justice in Sierra Leone and Liberia. New York: Tauris Academic Studies.
} 
and LURD group, though self-proclaimed as the liberators of the country, was just a large band of armed kids, motivated only by greed. They had their own agenda: reaching absolute power and wealth through terror. And Liberian people, especially women and children, were the ones who suffered the most. Hunger, violations, murder, mutilations were some of the many horrors this people faced every day.

Pray the Devil Back to Hell is a documentary, released in 2008 and directed by Gini Reticker, that tells the unknown story of a group of Liberian women, angry and tired of seeing their children, their families and their friends suffer. A group of women that, aware of their gender, decided to put an end to the massacre, and actually did, using the only two weapons they had: prayers and femininity.

"We are mothers, grandmothers, aunts and sisters. For us, this is only the beginning". With those words Leymah Gbowee, young mother of two little children, intended to persuade the group of women she had managed to gather in the Christian church she attended. She had had a dream: someone told her that she was to gather every woman in her church and start praying for peace. She called the initiative "Christian Women for Peace". That was all she aimed to do. What she didn't expect was the movement to take force by itself. Muslim women quickly joined the group, claiming that they could help with their prayers, though differently, because that was a problem that affected every woman in Liberia, not only Christians. Slowly, the movement started to grow and was named "Women of Liberia".

After several praying meetings, worried because the war was getting worse, Women of Liberia organized their first peaceful protest for peace. They tied up their hairs and didn't wear makeup, nor colorful dresses. They wore white, to express their intention for peace. In April 2003, thousands of Christian and Muslim Liberian women started to sit, day after day, at president Charles Taylor's way. Their placards said "Women of Liberia want peace now". But Taylor just ignored them.

Gbowee suddenly came up with a different idea. Perhaps they lacked political power, but they did have feminine power. "We said to women: one way or another, you have a power as a woman. And that power is to deny your body to your man, and tell him why you deny it to him. If you have any power to stop the war, you must use it". Gbowee's argument was that war was every man's guilt, either for commission or for omission. Maybe their husbands weren't shooting guns, but some way or another there was something they could do, as men. And they, as women, were going to press them to do whatever necessary. And it worked. Men started to react to their spouses' pressure: they 'confessed' their wives at home about what they were doing, or what they didn't because they couldn't help it. And women 
responded with positive reinforcements towards their husbands: "at least it's a good beginning".

Despite the shy efforts of the Women's husbands, war was still advancing. Charles Taylor and the LURD group refused to negotiate, even when there were now international calls to do so. Women of Liberia moved one step forward, and sent an official statement to the government demanding the dialogue to take place. In addition, they intensified their peaceful marches, adding more women in white every time. Taylor could not ignore them anymore: they were too many, and too visible, so he agreed to meet the leaders. Gbowee knew Taylor well enough to know that he could receive her smiling and kill her the minute after. Far from frightening, she prepared her speech carefully, thinking that that meeting was the best she could ever have asked for. In a public act, she handed Taylor a document with the Women's request: the president had to participate in the talks table. Surprisingly, Taylor consented: he thought it was not prudent to refuse Gbowee's demand, because Women of Liberia counted with too many supporters all along the country.

Negotiations started in Ghana, most of the African leaders were present, and the movement managed to get some of the women to travel and make presence and pressure. They resumed their protests in white, but they also did underlying diplomatic and political work: they talked unofficially with the main African leaders, going from one hotel to another. In that way, they were perfectly advised of every movement, every plan, and they used that information to negotiate between bands. Their methods were so serious, and they used their intelligence and soft abilities so well, that Abdulsalami Abubakar, the main leader directing the negotiation table, recognizes: "we took women completely seriously. I saw them as allies, as mediators. We considered that women were doing something positive, trying to make men reason".

During negotiations, Taylor was accused of war crimes in Sierra Leone, and voice was spread that he was about to be prosecuted internationally. After hearing the rumors, Taylor run back to Liberia and intensified his army, which made situation in Liberia much worse and more violent. Meanwhile in Ghana, after month and a half of dialogues and no agreements, the parts were tired and discouraged. But Women started to get nervous because they knew how unbearable the situation in Liberia was. They created a barrier around the negotiation headquarters, and risking arrest, demanded quick solutions: nobody was leaving the building until there was some advance. Abubakar endorsed them, and two weeks after, the parts signed the negotiations terms on August $18^{\text {th }}$ 2003. Terms were the following: Taylor was going to be exiled to Nigeria, the United Nations would pacify Monrovia, and a temporary government would organize democratic elections. 
Women of Liberia had had their victory, but after returning to Liberia, they still had work to do: supervise carefully the United Nations pacification and disarmament process, the temporary government and the peace treaty, because peace is something that must be built. Political treaties wouldn't guarantee it. As one of the activists express: "we must accept the fighters among us. We cannot be resentful. And though sometimes I refuse to forgive this guys, then I think: how can we move forward if we don't?". Besides, as far as Gbowee saw the issue, "it was men who made all mistakes. They brought war, poverty, pain, everything. This time, women were willing to do things differently".

Finally, they got involved in the elections. Organizing a strong campaign, and taking advantage of the respect they had earned among their countrymen, they were able to put Ellen Johnson-Sirleaf as the favorite candidate. On November $8^{\text {th }} 2005$, Johnson-Sirleaf is elected as the first female president of Liberian history. On 2011, Leymah Gbowee received the Nobel Peace Prize. In an interview for the International Day of Women, the feminist leader said:

The Liberian women peace movement demonstrated to the world that grassroots movements are essential to sustaining peace; that women in leadership positions are effective brokers for peace; and the importance of culturally relevant social justice movements. Liberia's experience is a good example to the world that women -especially African women- can be drivers of peace ${ }^{9}$.

\section{Analyzing Movements from a Feminist point of view: Individualistic and Relational Wings}

At first glance, it would seem there is almost nothing, or very little, in common between Femen and Women of Liberia. Completely different groups, with totally different stories, aims and methods, and yet both considered feminist movements ${ }^{10}$. This is perfectly consistent with the first idea I mentioned ahead: that it's not easy to know exactly what feminism is. As for the documentaries, one might tend to identify Ukraine is Not a Brothel with feminism, better than Pray the Devil Back to Hell. Nevertheless, the latter is considered as a highly feminist documentary in the critics. Furthermore, it is Leymah Gbowee, rather

9 (2014, March 8). Retrieved July 22, 2016, from http://www.globaleducationmagazine.com/ international-women's-day-interview-leymah-gbowee/

${ }^{10}$ It is interesting to notice that Women of Liberia, and in general, African women movements have been recognized as feminists by Western individualistic feminists, which consider those movements as the seed of their much more advanced feminism. As for African women, they are quite indifferent about how Western people name them: they are more interested in achieving their aims than to investigate their political label. For a Western feminist insight of African gender movements, cf. Mikell, G. (1995). African Feminism: Toward a New Politics of Representation. Feminist Studies, 21(2), 405-424. 
than Inna Shevchenko, the one that has received prizes, not just the Nobel Peace Prize, but also the Gruber Rights of Women Prize ${ }^{11}$ (2009) and the Women's eNews Leaders for the 21st Century Award (2008), among many others. How can we consider feminism in a way that embraces both movements and both documentaries? The University of California historian, Karen Offen, attempts to define feminism as

\begin{abstract}
A concept that can encompass both an ideology and a movement for sociopolitical change based on a critical analysis of male privilege and women's subordination within any given society [...]. Feminism opposes women's subordination to men in the family and society, along with men's claims to define what is best for women without consulting them; it thereby offers a frontal challenge to patriarchal thought, social organization, and control mechanisms. It seeks to destroy masculinist hierarchy but not sexual dualism (Offen 1988: 151).
\end{abstract}

It is possible to consider as a feminist, in Offen's opinion, any person who can demonstrate with actions that: (1) he or she accepts woman's opinion on society as valuable, despite the role that traditionally has been given to her; (2) he or she is conscious and upset about inequality that women live before masculine's privilege; (3) he or she takes concrete actions in order to defeat such inequality (Offen 1988). Seen that way, it is now possible to find a common field where Femen and Women of Liberia can stand together. And along with them, Simone de Beauvoir and Edith Stein, Virginia Woolf and Sor Juana Inés de la Cruz. They all share the purposes Offen suggests as requirements for feminism. But, how is it that those figures differ so much? Many Christian women, for example, would feel deeply inspired by Stein's or Gbowee's feminism, and reject Beauvoir's or Shevchenko's. The American scholar explains that. She distinguishes between two categories, two distinct modes of discourse that feminism has adopted in behalf of women's emanchipation. She calls these two categories 'relational' feminism and 'individualistic' feminism. The first wants to emphasize woman's rights and contributions as women, psychologically, physically and emotionally different, therefore complementary, to men. A relational feminist firmly endorses the idea that there is a human nature, and it is either feminine or masculine. Society works well only if it recognizes such a difference, and it grants equal value and rights to both sexes.

In other words, relational feminism combined a case for moral equality of women and men with an explicit acknowledgement of differences in women's and men's sexual functions in society [...]. Increasingly, relational feminists called for governmental programs that would bolster and enhance women's

${ }^{11}$ The Gruber Rights of Women Prize is an annual award, given by the Gruber Foundation from the University of Yale, to those persons who have made significant contributions to achieve gender equality.

Araucaria. Revista Iberoamericana de Filosofía, Política y Humanidades, año 19, n 38 . Segundo semestre de 2017. Pp. 121-139. ISSN 1575-6823 e-ISSN 2340-2199 doi: 10.12795/araucaria.2017.i38.06 
performance of procreative functions even as they argued that other avenues for

life-work must also be available to women (Offen 1988: 139).

On the other hand, individualistic feminism focuses in personal autonomy, rejecting every traditional gender role, (especially) including procreative functions and its responsibilities. On this basis, individualistic feminism seeks the exaltation of every individual right and personal fulfillment in any way chosen. Nature is, for individualistic feminism, seen as an obstacle and an enemy, because it holds a binary distinction between sexes that inevitably leads to a gender-role division always controlled by a patriarchal power. Though both individualistic and relational feminism have the same historical roots (that is, the consideration that women's situation in culture is unjust due to political institutions ruled by men, situation that could be changed with certain political actions) as Offen explains, the individualistic arguments seem to be, since the 1970 's, the only politically correct between the American women. It is also the one that has more power in the current century, and the general identification of the whole feminist movement with its individualistic wing would explain why women that stand for family, marriage and maternity tend to oppose feminism. But, as Offen points out, "the last decade of historical scholarship teaches us that to look only to individualist feminism is to miss the rich historical complexity of protest concerning women's subordination, even in the Englishspeaking world. It constitutes one important band, one significant possibility, on the broad spectrum of feminist thought" (Offen 1988: 138).

The two documentaries chosen and the feminist movements they present are good examples of each kind of argument. Femen represents individualistic feminism, because the "bare breast method" in a certain way tries to subjugate nature to the individual's own purposes in a double way. First, since Femen girls are willingly using their body as a political tool, then body belongs to a nature category that is susceptible of being used in the way the individual wishes (which implies, of course, a dualistic divorce between body and self). Second, Femen girls demand men to look straight at them, naked, and not see them as sexually desirable but politically and ethically valuable, claim which is a disregarding of the nature of sexuality, particularly men's sexual biology ${ }^{12}$.

${ }^{12}$ Femen girls do seek to provoke. They call their method 'sextremism'. But they use it to "provoke patriarchy into open conflict by forcing it to disclose its aggressive antihuman nature to fully discredit it in the eyes of history [...]. Sexist style of the actions is a way to destruct the patriarchal understanding of what is the destination of female sexuality to the benefit of the great revolutionary mission. Extremal nature of sextremism demonstrates intellectual, psychological and physical superiority of female activists from FEMEN over the bandogs of patriarchy" (Retrieved September, 1st 2016, from http://femen.org/aboutus/). Such an assessment implies the idea that men's way of living sexuality (that is, watching women's naked body and sexually desire her) is depraved and 'antihuman' in itself, because it leads men to want to possess women and use them as objects. Femen girls seem to identify men's sexual biological functioning with sexual perverted and violent actions. By treating the second as the first, they try to impose some sort of sexual morality towards men's biological way of living sexuality, which they reject and despise. 
The former regards only Femen in its method, not in its original aim. As far as the documentary presents Femen's aim, the Ukrainian girls' requests were perfectly understandable. Nevertheless, after Ukraine is Not a Brothel was released, Victor Sviatsky had to left Femen, and the current leaders are Inna and Sasha Shevchenko. Without Victor's commands, the girls started to lead Femen in the directions they wanted. Though it had always been in its agenda, Femen started to make 'world tours' more often, to stand for the rights of LGBT people, and for free abortion. Femen movement started to make presence and gain new leaders and activists within almost all Europe and America as well. The aim of the movement broadened, and now not only its method, but also its goals suggest individualistic feminism, for it now doesn't only requires woman to be taken seriously by society, but it wants women (and men) to be released of every traditional sexual role. It shouldn't be any surprise, though, because the very method they were using already implied the nature of body as usable at will.

Women of Liberia, on the other hand, represent relational feminism because it's a movement that tries to give a whole country the care of a mother. Both its goals (gaining a peaceful environment to form their families and raise their children) and its methods reveal feminism in its attempt to make society appreciate what women can do when they see and do things their way. Liberian feminists never intended to fight for individual rights, and even less to get rid of their role as mothers and wives. On the very contrary: they entered politics precisely because they wanted to protect those aspects of their lives. And for them, both things weren't incompatible. Instead, they were complementary: women could do better political work than men at that particular moment because they knew better than men how family worked and what it needed desperately, and hence, what society needed desperately.

Politically speaking, it is interesting to analyze if the movements achieved a political relevant position and why. My insight is that Femen girls, though increasingly famous, haven't reached political respect ${ }^{13}$. Initially, that could be explained by the reality of the movement that Ukraine Is Not a Brothel came to light, that is, that is was actually a patriarchal movement controlled by a violent dominative man. That could have diminished Femen's success because of its inner contradiction. But the main problem is not that contradiction, but the one that concerns prostitution and pornography. Since Femen girls use their own naked body for political reasons, for it's the best way for them to

13 This could be arguable precisely due to their fame. Femen girls are called from almost every country in Europe to make and settle their 'trademarked' protests, and they do generate political pressure. But I don't understand here 'political success' or 'political respect' in terms of general support or noise generated. My point here is to show whether they earned men's respect as equally valuable from an ethical, social and political ground or not, because, in the end, that is the whole point of a feminist movement. 
catch men's attention in order to stop getting prostituted, they are, in a political way, equally selling their bodies for a goal. They are still using their bodies to catch men's eyes, creating 'political porn', as Green showed at the beginning of the documentary. Even without Victor's presence, these girls cannot escape from being exploited, because they exploit themselves willingly. That obvious contradiction between goal and method is the true reason, from my point of view, that doesn't allow Femen to earn political respect. The way men treat them (from the last policeman that calls them 'whores' until the legislative power that criminalized them) is a sign of this.

Kitty Green is not the only Femen activist that has tried to bring the inner life of Femen to light ${ }^{14}$. On 2015, the ex-leader of Femen Brazil, Sara Winter, released a short digital book named Vadia, Não! Sete vezes que fui traida pelo feminismo ("Not a Whore! Seven Times That I Was Betrayed by Feminism"). She intends to "share the behind-scenes of current feminist Brazilian movement" (Winter 2015: 1), because, during the years she spent as leader of the movement, she learned that she had to be frightened of feminism. Her main message is to show that Femen's feminism (and, from her point of view, feminism itself, since she identifies it with the individualistic branch) is not really interested in real troubled women, but in a general ideology that doesn't really help women but destroys them. The reason is not only that they use themselves. In a few years, that disguised violence against women reached new horizons. Winter shows that the feminism she knew from the inside is perfectly willing to psychologically liquidate any woman who, knowingly or not, diverges from the expected discourse or behavior. The seven chapters of the book shows seven examples in which that inconsistency between speech and actions takes place. For Sara, the damages of such incoherence reached her life. She made herself a feminist thinking that she would find a solace in her troubled past, that she was going to be understood and accompanied as a woman by her feminist partners. But she found herself used, compelled to do what she wouldn't do by her own will (like taking drugs -something she always refused to do, despite the pressure-, or declaring herself bisexual in order to have credibility), and even sexually harassed by a lesbian. She only found individual interests and interested relationships where she thought she would find true friendship. "I suffered cold, and remained seated by a corner watching people pass through, drinking, happy, laughing and jumping, while I cried devastated without understanding why a woman, a feminist, a sister of fight, had abandoned me in hunger, tiredness and cold, so much cold. Shouldn't she shelter me, help me? She just easily changed me for sex and drugs" (Winter

${ }^{14}$ It is important to say that Kitty Green never intended to bring Femen down. She was only trying to unmask Victor, not the movement itself. She is still part of the Femen movement, which she believes is a better and solid institution now Svyatski is gone. 
2015: 21). By the end of her 'career' in Femen, a few mistakes in her behavior and using of language led her to total rejection among her flag sisters. She was about to commit suicide several times. In Sara Winter's opinion, her activist partners in Femen and feminist movements failed in the most important issue, precisely the one they should never fail in: protecting women, because, as I said above, their political method and aim ends up using women's bodies and, as Winter shows, minds and ideals as well.

In the last decades, individualistic feminism (that has always tried to eradicate the gender-role traditionalism) have focused in emphasizing individual's autonomy and rights in choosing their way of living their sexuality, claiming that gender is nothing but a cultural construction. In their attempt of giving their demands philosophical grounds, individualistic feminists have adopted Derrida's deconstructionist philosophy, Foucault's understanding of sex, and Freud's and Lacan's psychoanalyst method. Feminists thinkers like Judith Butler, Iris Marion Young or Joan Scott have ended up concluding that gender roles are cultural, but so is sex itself ${ }^{15}$. Hence, natural differences between men and women in every thinkable way are completely blurred and broken. Though the idea was to gain complete equality and absolute autonomy, this attempt ends up betraying women instead. Since biological and psychological differences are vanished in order to avoid any gender role to be imposed to women (or men - to include here gay and transgender people in general), then the possibility for women to have a social value precisely because of their gender also vanishes, and therefore, the very aim of feminism is deconstructed along with genders, sexes and subjects. Femen girls, as the image of individualistic feminism, also represent it in its consequence: selfdestruction. It is the fierce searching for the self whatever the consequences that leads individualistic feminist to annihilation, because in its discourse it aims to protect women in society, but in practice it deconstructs them and even harms them, as Sara Winter shows, if they diverge from what individualistic feminism have decided is acceptable to say and do for achieving their purpose. As a consequence, they damage the individual by staunchly trying to protect individualism.

Since society gets harmed when individuals do, the former shows why many women, those that would normally try to marry, have children, divide tasks in their homes with their husbands, find a job, and receive a fair salary in their workplaces, feel some sort of fear or rejection towards individualistic feminism. Yet, that should not be a reason for those women to reject feminism in general. As Women of Liberia demonstrated to the world, women defending their rights and place in society can improve it. In a couple of years, Women of Liberia achieved what Femen hasn't in almost a decade. Besides stopping

15 This is what Judith Butler called performativity or queer theory. 
a war (which should be enough by itself), they earned international respect from political figures all around their continent, complete social acceptance, and enough political intervention to gain votes for the first female president in their country. Their method was completely in accordance with their goal: they wanted peace, they would achieve it peacefully. They wanted their leaders to be reasonable, they used reason. And, as every feminist, they wanted men to recognize the worth of a woman's work, so they gave the best of themselves using reason properly and strength of character, like men $\mathrm{do}^{16}$, but adding empathy and care for the weak as equally important values ${ }^{17}$.

One could argue that, just as Femen girls reinforced the image of women as prostitutes by behaving as such, Women of Liberia reinforced at the same time gender stereotypes by behaving peacefully, gently, and even using their body as their husband's sexually pleasurable source. Nevertheless, that would only be true if they haven't moved into the political and public sphere, acting differently from what women were expected to, regarding their gender role. What's interesting of their way of proceeding is that they did break some of the traditional gender roles - which is why we can call them feminists according to Offen's definition-, but only those that didn't allow women to provide a genuine social contribution. Their methods and aims weren't developed in a way that attempted against themselves as women. This is consistent with relational feminism: women can also contribute to society, not diminishing or annulling what men do, but adding complementary values. Yet, for the word 'complementary' to have a meaning, it is necessary to recognize and respect both the similarities and the differences between the sexes.

Leymah Gbowee and Women's of Liberia's requests and methods also implied the consideration that there are higher aims than merely individual interests that are worth fighting for. In fact, the extreme searching for own interests can lead to serious damage to society, and what men and women should consider is to be able to build their lives within a healthy community that also watches over family's and neighbor's welfare. Perhaps this is the most important difference between Femen as individualistic feminism and Women

16 Though Gbowee would say that, in this particular case, men weren't using neither reason nor real strength of character. So, if they wouldn't work well not even in those aspects, Women of Liberia would have to replace them also in reasonableness and strength.

17 The fact that empathy and care for the weak are feminine features is highly debated, precisely because it is argued that there are feminine or masculine personality features at all (or even feminine or masculine physical features, as queer theory mentioned above defends). Here I am taking position, without defending it to avoid deepening in the matter, in favor of the existence of such psychological and personality features according to gender. For literature about this particular subject, cf., for example, Hoffman, M. (1977). Sex Differences in Empathy and Related Behaviors. Psychological Bulletin 84(4):712-722; Koehn, D. (1998). Rethinking Feminist Ethics: Care, Trust, and Empathy. London: Routledge; Strauss, C. (2004). Is Empathy Gendered and, If so, Why? An Approach from Feminist Psychological Anthropology. Ethos, 32(4), 432-457; Thompson, A. (2003). Caring in Context: Four Feminist Theories on Gender and Education. Curriculum Inquiry, 33(1), 9-65. 
of Liberia as relational feminism: that while Femen fights for the benefit of part of the population, that is, women (though, as Sara Winter shows, even that is uncertain: it would be more accurate to say that they are fighting only for personal activists' benefit but in groups), Liberians worked for the good of the whole community. We could then conclude that, for political aims, women will gain a place in community once they participate actively, as Liberians did, in the public sphere as reasonable citizens that search the benefits of the whole population they are part of.

One could wonder whether is worthy, or even possible to use the word 'feminism' to refer to its relational branch, since individualistic feminism seems to have completely taken over the term. Yet, if Karen Offen is right, forgetting relational aspects of feminism is not only to forget its origin, but also to miss valuable aspects of the movement that could be endorsed by many women that now tend to reject feminism. Furthermore, since individualistic feminism inherently entails self-destruction, relational feminism ideas and contributions could be a way for the movement to save itself. And since current public policies, at least in Western society in general, have not only accepted but are also encouraging women's involvement in every social role, relational feminism could have high probabilities of success. Paradoxically, its greatest enemy wouldn't be patriarchy now, but individualistic feminism, against which relational feminism should need to oppose to protect families... and women. 


\section{References:}

Everill, B. (2013). Abolition and Empire in Sierra Leone and Liberia. Hampshire: Palgrave Macmillan UK.

Harris, D.J. (2012). Civil War and Democracy in West Africa: Conflicts, Resolutions, Elections and Justice in Sierra Leone and Liberia. New York: Tauris Academic Studies.

Kubicek, P (2008). The History of Ukraine. Westport: Greenwood.

Magocsi, P.R. (2010). A History of Ukraine: The Land and Its People ( $2^{\text {nd }}$ ed.). Toronto: University of Toronto Press.

Mikell, G. (1995). African Feminism: Toward a New Politics of Representation. Feminist Studies 21(2), 405-424.

Offen, K. (1988). Defining Feminism: A Comparative Historical Approach. Signs 14(1), 119-157.

Plokhy, S. (2015). The Gates of Europe: A History of Ukraine. New York: Basic Books.

Subtelny, O. (2009). Ukraine: A History. Toronto: University of Toronto Press. Waugh, C. (2011). Charles Taylor and Liberia: Ambition and Atrocity in Liberia's Lone Star State. London: Zed Books.

Winter, S. (2015). Vadia, Não! Sete vezes que fui traída pelo feminismo. FICM ed. (Only available digitally). 
